\title{
Modelling of the shear resistance of self- stressed beams reinforced with FRP applying the Critical Shear Crack Theory
}

\author{
Viktar Tur ${ }^{*}$, Aliaksandr Varabei ${ }^{1}$ \\ ${ }^{1}$ Brest State Technical University, Brest, Belarus
}

\begin{abstract}
This paper presents a mechanical model of the shear resistance based on Critical Shear Crack Theory (CSCT) and its application for the checking of the shear ultimate state of self-stressed elements reinforced with FRP bars. The shear force, which is transmitted through the inclined crack by aggregate interlock, residual tensile strength, dowel action and inclined chord of the compression concrete, is calculated depending on the value of the inclined crack opening, determined according to the modified law "bond-slip" for FRP bars. The reliability of the proposed approach is confirmed by comparison both with the results of our own experimental investigations and with numerous research results by various authors.

Keywords: shear resistance, modified law "bond-slip", model of CSCT, FRP bars, beam.
\end{abstract}

\section{Introduction}

In recent construction practice, it is recommended to use fiber-reinforced polymer composites (FRP) bars as an alternative to traditional steel reinforcement of concrete elements. This is due to the fact, that this type of reinforcement has high corrosion resistance, low density and high strength in relation to steel. However, because of the low modulus of elasticity, which is comparable to the modulus of elasticity of concrete, it imposed several restrictions, especially when using such type of reinforcement in the bending elements. Additional restrictions are associated with different values of the coefficients of thermal linear expansion in the longitudinal and transverse directions [1].

Despite the increase in the production of polymer composites, their practical application remains limit, both due to the significant variability of their properties from different manufacturers, and the limited design models included in the design standards for traditional reinforced concrete structures or the special guides. Most models of shear resistance of FRPreinforced elements introduced in codes and standards differ from the design shear resistance models for elements with traditional reinforcement only by the ratio of the elastic moduli of FRP and steel reinforcement $E_{f} / E_{s}$ (for example, ACI 440-15 [2], ISIS-M03-01 [3], JSCE 97 [4], BISE-99 [5], CNR-DT203-2006 [6], ACI 318 [7]). At the same time, the question of whether the design models of the shear resistance of FRP-reinforced elements should be included in the general standards, or whether it is necessary to create special standards,

\footnotetext{
*Corresponding author: profturvic@,gmail.com
} 
remains open for discussion. In particular, in the design of concrete members reinforced with FRP bars, the effect, for example, of increased deformability of FRP bars on shear resistance mechanisms, should be established. So, according to general concepts, when using FRP-bars as a longitudinal reinforcement, cracks with a wider opening are formed in bending elements compared to elements reinforced with steel bars. In this paper, we present some propositions for modification of a mechanical model of the shear resistance of concrete elements reinforced with FRP bars, based on the Critical Shear Crack Theory (CSCT) [8]. Here, in contrast to the known model, the width of the inclined crack opening at the level reinforcement level is determined using the law "bond-slip" for FRP bars included in fib Model Code 2010 [9]. The results of verification of the modified calculation model of shear resistance model against the background of our own experimental data showed satisfactory agreement and made it possible to develop a failure criterion for FRP-reinforced elements without shear reinforcement.

\section{Some basic assumptions of Critical Shear Crack Theory (CSCT)}

The critical shear crack theory (CSCT) proposed by Muttoni et al. [8] relies on a mechanical approach that takes into account the contribution of all possible of the sheartransfer actions. A detailed description of the CSCT, and also the contribution of the sheartransfer actions, are presented in [10-13]. This theory based on the assumption that the shear resistance of reinforced concrete elements without stirrups and the deformation capacity are related by the failure criterion, while lower values of the shear resistance are associated with a high deformation capacity, and therefore a wider crack opening. This assumption means that the width of the critical shear crack opening is proportional to the product of the longitudinal strains of reinforcement in the control section by the effective depth of the element $w \infty \varepsilon_{s} \cdot d$. According to the research results presented in [13], cracks at a short distance can develop at the level of longitudinal reinforcement, after which they incorporate, and the sum of all cracks related to the critical shear crack gives an approximate linear profile of the horizontal component of the crack opening width (see Figure 1).

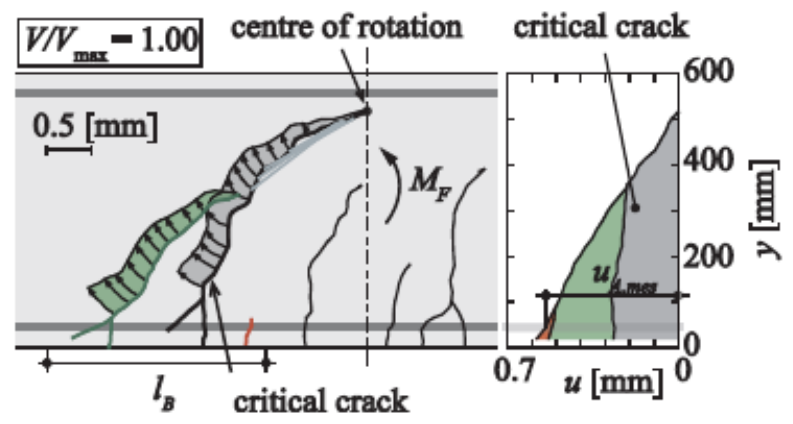

Fig. 1. Crack kinematics, center of rotation and horizontal opening $u_{A}$ of the cracks tributary to the opening of the critical shear crack in a region of length $l_{B}[13]$

It should be noted that this form of notation $\varepsilon_{s} \cdot d$ assumes a uniform distribution of strains $\varepsilon_{s}$ along the length $l_{b}$.

This tributary length is practically constant at peak load [13] and can be approximated by the expression:

$$
l_{b}=d-c,
$$


where $c$ is the depth of the compression zone of concrete.

Based on [14], it was proposed to calculate the horizontal component of the inclined crack opening width by the following expression:

$$
u_{A}=\varepsilon_{s} \cdot l_{b}
$$

Taking into account that the width of the inclined crack opening is the main basic variable in the model of shear strength CSCT and the value $l_{b}$ is obtained experimentally [13], the question arises about the applicability of expression (2) for the case of concrete elements reinforced with FRP bars.

In this regard, it was proposed to make adjustments to the original CSCT model, related to the determination of the crack opening width, based on the "bond-slip" law for FRP bars.

\section{Inclined shear crack opening depending on the development length along the longitudinal reinforcement}

According to the proposed model, the width of inclined crack opening in elements reinforced with FRP bars, depending on the force (stress) in the longitudinal reinforcement, is determined from the following expression:

$$
w_{A}=u_{A}=2 \cdot s\left(l_{b}\right)
$$

where $s\left(l_{b}\right)$ - end slip depending on the development length.

The value of the end slip of FRP bar is determined by the modified "bond-slip" law proposed by Eligehausen et al [15] (see Figure 2) and the procedure for determining the development length of FRP bars proposed by Cosenza et al [16].

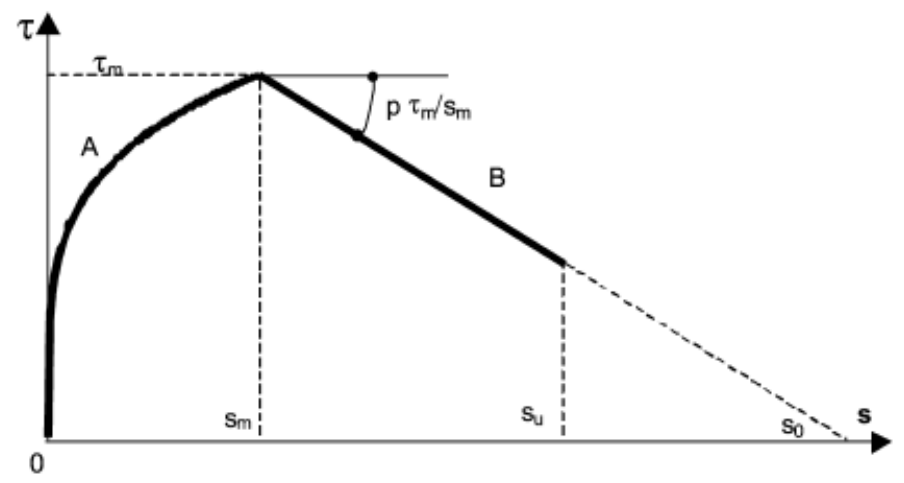

Fig. 2. Modified “ $\tau-s$ ” law [15]

The analytical solutions proposed in [16] make it possible to obtain slip, normal stresses, and bond stresses distributions along the reinforcing bar, and also make it possible to determine the development length.

The procedure for calculating the crack opening width starts with determining the tensile stresses $\sigma_{s}$ in the reinforcing bars in the design section of the element according to the following simplified expression: 


$$
\sigma_{s}=\left(\frac{M_{E d}}{z}+\frac{V_{E d}}{2} \cdot \cot \theta\right) \cdot \frac{1}{A_{s}}
$$

where $M_{E d}$ - bending moment at the design section;

$z=0,9 \cdot d$

$V_{E d}$ - shear force at the design section;

$\Theta$ - angle of inclination of the shear crack to the longitudinal axis;

$A_{s}$ - cross-sectional area of bars.

There are two design cases depending on the values of tensile stresses: case 1- if $0<\sigma_{s} \leq \sigma_{1}$ (ascending branch of the " $\tau-s$ " diagram (see Figure 2), where $\sigma_{1}$ are tensile stresses in reinforcing bars corresponding to slip $s_{m}$ (peak point of the " $\tau$-s"); case 2 - if $\sigma_{1}<\sigma_{s} \leq \sigma_{2}$ (softening branch of the " $\tau$-s" diagram (see Figure 2), where $\sigma_{2}$ are tensile stresses in reinforcing bars corresponding to slip $s_{0}$ (see Figure 2).

The values of tensile stresses $\sigma_{1}$ and $\sigma_{2}$, according to [16], can be determined by expressions (5) and (6), respectively.

$$
\sigma_{1}=\sigma\left(s_{m}\right)=\sqrt{\frac{8 \cdot E_{f}}{\varnothing} \cdot \frac{\tau_{m} \cdot s_{m}}{(1+\alpha)}}
$$

where $E_{f}$ - elastic modulus of the FRP bar;

$\varnothing$ - bar diameter;

$\tau_{m}-$ maximum bond strength;

$s_{m}-$ slip at peak bond strength;

$\alpha$ - coefficient which describes the ascending branch " $\tau-s$ " law [15].

$$
\sigma_{2}=\sigma\left(s_{0}\right)=\sqrt{\frac{8 \cdot E_{f}}{\varnothing} \cdot A_{\tau, \max }},
$$

where $A_{\tau, \max }=\frac{\tau_{m} \cdot s_{m}}{1+\alpha}+\frac{\tau_{m} \cdot s_{m}}{p}$

$p$ - coefficient which defines the softening branch " $\tau$-s" law [15].

For case $1\left(0<\sigma_{\underline{s}} \leq \sigma_{\underline{I}}\right)$

The value of the slip corresponding to the stresses in the reinforcing bar $0<\sigma_{s} \leq \sigma_{1}$ is determined by the following expression, according to [16]:

$$
s\left(l_{b}\right)=\left[\frac{2 \cdot \tau_{m}}{E_{f} \cdot \varnothing \cdot s_{m}^{\alpha}} \cdot \frac{(1-\alpha)^{2}}{(1+\alpha)}\right]^{1 /(1-\alpha)} \cdot l_{b}^{2 /(1-\alpha)} \leq s_{m},
$$

where $l_{b}-$ the development length which is determined by the expression (9):

$$
l_{b}=l_{0} \cdot\left(\frac{\sigma_{1}}{\sigma_{s}}\right)^{2 \cdot \alpha /(1+\alpha)} \cdot\left[\frac{1+\alpha}{1-\alpha}\right]
$$




$$
l_{0}=l_{0}\left(\sigma_{s}\right)=\frac{\varnothing \cdot \sigma_{s}}{4 \cdot \tau_{m}}
$$

Further, the width of the inclined crack opening is determined by expression (3).

For case $2\left(\sigma_{1}<\sigma_{\underline{s}} \leq \sigma_{2}\right)$ [16]:

In this case, the value of slip is determined from the following expression, according to

$$
\begin{aligned}
& s\left(l_{b}\right)=\frac{1}{p} \cdot\left[1+p-\cos \left(w \cdot\left(l_{b}-l_{m}\right)+\sqrt{\frac{2 \cdot p}{1+\alpha}} \cdot \sin \left(w \cdot\left(l_{b}-l_{m}\right)\right] \cdot s_{m},\right.\right. \\
& \text { where } w=\frac{1}{l_{m}} \cdot \sqrt{\frac{2 \cdot p}{1+\alpha}} \cdot \frac{(1+\alpha)}{(1-\alpha)} \text {, } \\
& l_{m}=\frac{\sigma_{1} \cdot \varnothing}{4 \cdot \tau_{m}} \cdot \frac{(1+\alpha)}{(1-\alpha)} \\
& l_{b}=l_{m} \cdot\left[1+\sqrt{\frac{(1-\alpha)^{2}}{2 \cdot p \cdot(1+\alpha)}} \cdot\left(\arcsin \sqrt{\frac{A_{\tau_{2}}}{A_{\tau_{\max }}}}-\arcsin \sqrt{1-\frac{\varnothing \cdot \sigma_{s}^{2}}{8 \cdot E_{f} \cdot A_{\tau_{\max }}}}\right)\right],
\end{aligned}
$$

As in the first case, the width of the inclined crack opening is determined by expression (3).

\section{Calculation procedure for the shear resistance of concrete elements reinforced with FRP bars according to the modified CSCT model}

The iterative procedure for calculation of the shear resistance of a beam element includes the following steps:

1) Choose a location of the critical shear crack $x_{A}$;

2) Take the value of the design shear force in the section $\mathrm{A}\left(V_{E d, A}\right)$;

3) Calculate the angle of the critical shear crack $\beta_{A B}$ as a function $\alpha_{A}=\frac{M_{E d, A}}{V_{E d, A} \cdot d}$ :

$$
\beta_{A B}=\frac{\pi}{4} \cdot\left(1+\frac{\alpha_{A}^{1 / 3}}{3}\right)
$$

4) Calculate the width of the inclined crack opening $w_{A}=u_{A}$ in the selected section $\mathrm{A}$ according to the proposed procedure (expressions (3)-(14)) depending on the force (stress) in the longitudinal reinforcement;

5) Calculate, as a function of the shape of the crack and its kinematics, the residual tensile strength force $V_{\text {Res }}$, the aggregate interlock force $V_{A g g}$, the dowel action $V_{\text {Dowel }}$, the contribution of the compression zone $V_{\text {Comp }}$ according to the provisions of the CSCT [14], take into account the width of the inclined crack opening defined in step 4. 
The shear capacity is as the sum of these contributions:

$$
V_{C, R}=V_{\operatorname{Re} s}+V_{\text {Agg }}+V_{\text {Dowel }}+V_{\text {Comp }},
$$

6) Compare $V_{E d, A}=V_{C, R}$. If this condition is not met, go to step 2 .

This iterative procedure should be carried out for sections $x_{A, i}$ along the length of the element's span and the minimum value $V_{C, R}$ is selected. We should consider this value as the ultimate shear force.

\section{Location of the critical shear crack and the contribution of the different shear-transfer actions under various loading conditions}

We carried our own experimental studies to estimate the accuracy of the proposed design model and to determine the control section $\mathrm{x}_{A}$. The experimental studies included 9 beam elements reinforced with FRP bars. Also, 7 beam elements with traditional reinforcement were tested to distinguish between the types of reinforcement. These beams were tested under various loading conditions (uniformly distributed load and point forces). Geometry, reinforcement arrangement and basic parameters of beams shown in Figure 3.

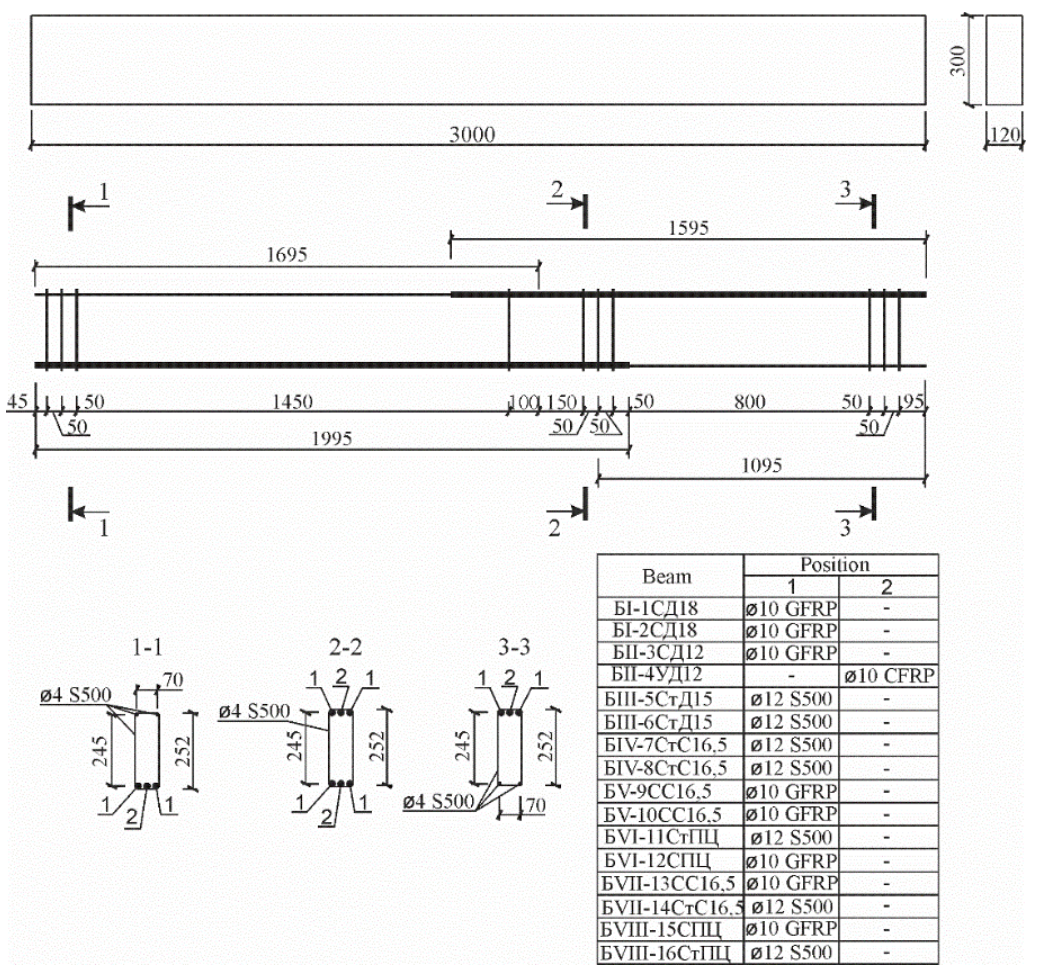

Fig. 3. Geometry, reinforcement arrangement and parameters of tested beams

The test beams were reinforced with bars GFRP $\varnothing 10$ (Maperod G and AKS 10), CFRP $\varnothing 10$ (Maperod C) and steel reinforcement Ø12S500. Main mechanical parameters of reinforcement are listed in table 1. 
Table 1. FRP reinforcement mechanical parameters

\begin{tabular}{|c|c|c|c|c|c|}
\hline Class & $\begin{array}{c}\text { Diameter } \\
\varnothing, \mathrm{mm}\end{array}$ & $\begin{array}{c}\text { Yield } \\
\text { strength, } \mathrm{f}_{\mathrm{yk}}, \\
\mathrm{MPa}\end{array}$ & $\begin{array}{c}\text { Strength, } \\
\mathrm{f}_{\mathrm{y}}, \mathrm{MPa}\end{array}$ & $\begin{array}{c}\text { Modulus of } \\
\text { elasticity } \\
\mathrm{E}_{\mathrm{f}} 10^{3}, \mathrm{MPa}\end{array}$ & Ultimate strain, \% \\
\hline Maperod G & 10 & - & 760 & 40,8 & 2 \\
\hline Maperod C & 10 & - & 2000 & 155 & 1,5 \\
\hline AKS 10 & $10^{*}$ & - & 1244 & 32 & 2,7 \\
\hline \multirow{2}{*}{ S500 } & 12 & 652 & 749 & 200 & - \\
\cline { 2 - 6 } & $12^{* *}$ & 678 & 778 & 200 & - \\
\hline
\end{tabular}

Notes:
1. «*» - this reinforcement was used in beams of the series БV, БVI-12CПЦ, БVII-13CC16,5 and БVIII-15СПЦ.

2. «**» - this reinforcement was used in beams of the series БIV, БVI-11СТПЦ, БVII-14СтC16,5 and БVIII-16СтПЦ.

In the own experimental study, Self-stressing concrete with different energy and Ordinary Portland-cement concrete were used (see Table 2).

Table 2. Main characteristics of concrete at the time of static tests

\begin{tabular}{|c|c|c|c|c|c|c|c|}
\hline \multirow{3}{*}{ Series } & \multirow{3}{*}{ Beam } & \multicolumn{4}{|c|}{$\begin{array}{l}\text { Mechanical concrete characteristics } \\
\text { at the time of static testes }\end{array}$} & \multicolumn{2}{|c|}{$\begin{array}{c}\text { Expansion characteristics of } \\
\text { concrete at the time of static } \\
\text { tests }\end{array}$} \\
\hline & & \multirow{2}{*}{$\begin{array}{l}\text { fcm,cube, } \\
\text { MPa }\end{array}$} & \multirow{2}{*}{$\begin{array}{c}\mathrm{f}_{\mathrm{cm}}, \\
\text { prizma, } \\
\mathrm{MPa}\end{array}$} & \multirow{2}{*}{$\begin{array}{l}\text { fcm, cyl, } \\
\mathrm{MPa}\end{array}$} & \multirow{2}{*}{$\begin{array}{l}\mathrm{E}_{\mathrm{cm}} \\
\mathrm{GPa}\end{array}$} & & \\
\hline & & & & & & $\begin{array}{c}\mathrm{ECE}, \mathrm{f}, \\
\%\end{array}$ & $\mathrm{f}_{\mathrm{CE}, \mathrm{k}}, \mathrm{MPa}$ \\
\hline \multirow{2}{*}{ I } & БІ-1СД18 & - & 51,1 & - & \multirow{2}{*}{31,7} & \multirow{2}{*}{1,12} & 1,8 \\
\hline & БІ-2СД18 & - & 55,1 & - & & & 1,1 \\
\hline \multirow{2}{*}{ II } & БІІ-ЗСД12 & \multirow{2}{*}{77,1} & \multirow{2}{*}{76,5} & \multirow{2}{*}{56,1} & \multirow{2}{*}{43,3} & \multirow[b]{2}{*}{ - } & \multirow[b]{2}{*}{ - } \\
\hline & БІІ-4УД12 & & & & & & \\
\hline \multirow{2}{*}{ III } & БІІІ-5СтД15 & 86,2 & 82,4 & 67,1 & \multirow{2}{*}{46,3} & \multirow{2}{*}{0,05} & 0,45 \\
\hline & БІІІ-6СтД15 & 86,2 & 82,4 & 67,1 & & & 0,50 \\
\hline \multirow{2}{*}{ IV } & $\begin{array}{c}\text { БIV- } \\
\text { 7CтC } 16,5\end{array}$ & 29,3 & 47,8 & - & \multirow[b]{2}{*}{29,8} & \multirow{2}{*}{0,64} & 2,70 \\
\hline & $\begin{array}{c}\text { БIV- } \\
8 \mathrm{C} \text { TC } 16,5\end{array}$ & 17,4 & 43,5 & - & & & 2,90 \\
\hline \multirow{2}{*}{ V } & 5V-9CC 16,5 & 58,1 & 52,0 & 34,5 & 32,7 & \multirow{2}{*}{0,45} & 1,80 \\
\hline & 5V-10CC16,5 & 54,6 & 54,4 & 32,3 & 34,7 & & 1,65 \\
\hline \multirow{2}{*}{ VI } & БVI-11СтПЦ & \multirow[b]{2}{*}{56,1} & \multirow[b]{2}{*}{47,1} & \multirow[b]{2}{*}{36,1} & \multirow[b]{2}{*}{40,5} & \multirow[b]{2}{*}{ - } & \multirow[b]{2}{*}{ - } \\
\hline & БVI-12СПЦ & & & & & & \\
\hline \multirow{2}{*}{ VII } & $\begin{array}{c}\text { БVII- } \\
13 \mathrm{CC} 16,5\end{array}$ & 29,2 & 50,2 & 21,9 & 31,2 & \multirow{2}{*}{0,42} & 1,90 \\
\hline & $\begin{array}{c}\text { 5VII- } \\
\text { 14CTC16,5 }\end{array}$ & 33,9 & 53,8 & 31,2 & 32,6 & & 1,95 \\
\hline VIII & $\begin{array}{c}\text { БVIII-15СПЦ } \\
\text { БVIII-16СтПЦ }\end{array}$ & 37,1 & 30,7 & 25,0 & 32,1 & - & - \\
\hline $\begin{array}{l}\text { Notes: } \\
f_{\mathrm{c}, \text { cube }}, \\
\mathrm{f}_{\mathrm{cm}, \text { prizl }} \\
\mathrm{f}_{\mathrm{cm}, \mathrm{cyl}} \\
\mathrm{f}_{\mathrm{CE}, \mathrm{k}}- \\
\varepsilon_{\mathrm{CE}, \mathrm{f}}-\end{array}$ & $\begin{array}{l}\text { ube compressiv } \\
\text { - mean concre } \\
\text { mean concrete } \\
\text { f-stresses grade } \\
\text { ain of free expa }\end{array}$ & $\begin{array}{l}\text { trength } \\
\text { compres } \\
\text { npressiv } \\
\text { ased on } \\
\text { ion base }\end{array}$ & $\begin{array}{l}8 \text { days } \\
\text { streng } \\
\text { rength } \\
\text { ms }(10 \\
\text { a cylin }\end{array}$ & $\begin{array}{l}\text { based o } \\
\text { sed on } \\
100 \times 40 \\
\text { s }(\varnothing 150\end{array}$ & $\begin{array}{l}\text { prism } \\
\text { inder } \\
\mathrm{nm}) ; \\
\mathrm{n}=300\end{array}$ & $\begin{array}{l}100 \times 10 \\
\qquad 150, \\
\text { m). }\end{array}$ & $\begin{array}{l}\mathrm{m}) \text {; } \\
\mathrm{m} \text {; }\end{array}$ \\
\hline
\end{tabular}

Beams were tested under static loading with monotonically increasing uniformly distributed load and point forces. Test setups are shown in Figure 4. 
a)

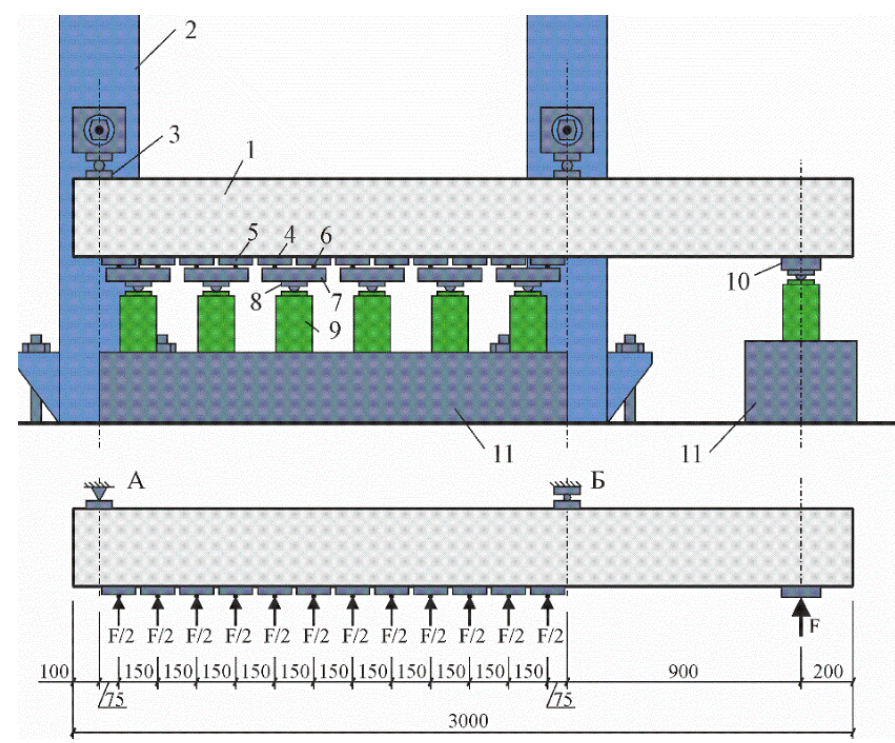

1 - experimental beam; 2 - 2 U-shaped steel frames connected to the strong floor; 3

-4 steel supports $(100 \times 200 \times 30 \mathrm{~mm}) ; 4-13$ rubber bearings; $5-12$ steel plates (130x130x30 mm); $6-12$ steel bars $(\varnothing 14 \mathrm{~mm}) ; 7$ - steel plates $(245 \times 155 \times 50 \mathrm{~mm})$;

$8-7$ steel hinges; $9-7$ hydraulic jacks $(250 \mathrm{kN})$;

10 - steel plates $(150 \times 150 \times 40 \mathrm{~mm}) ; 11$ - steel girders.

b)

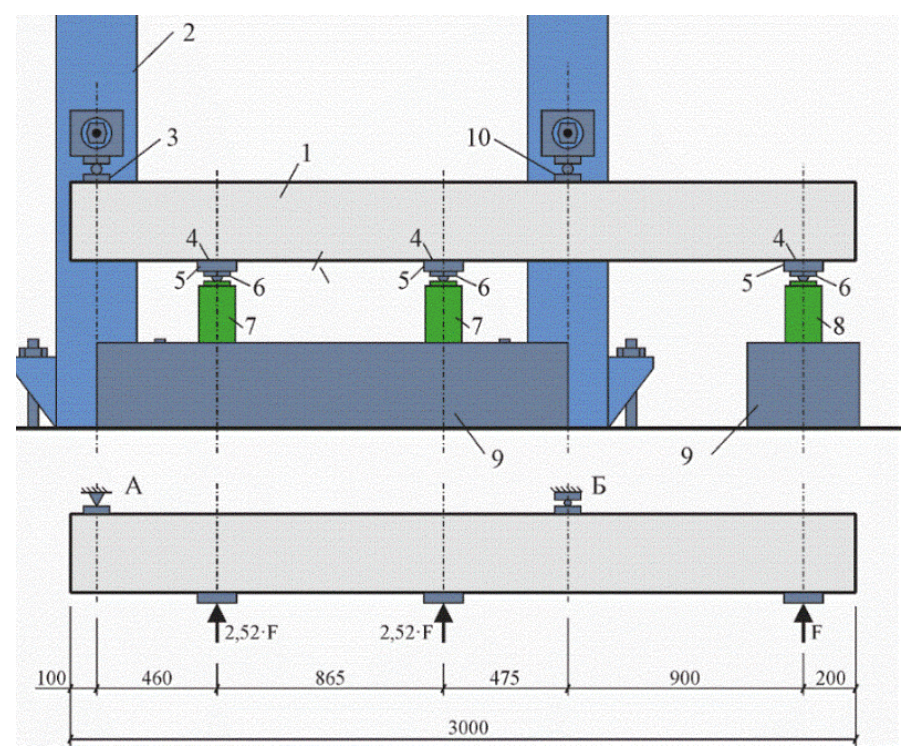

1 - experimental beam; 2 - 2 U-shaped steel frames connected to the strong floor; 3 - 4 steel supports $(100 \times 200 \times 30 \mathrm{~mm}) ; 4-3$ rubber bearings; $5-3$ steel plates $(100 \times 200 \times 30 \mathrm{~mm})$; $6-3$ steel hinges; $7-2$ hydraulic jacks $(250 \mathrm{kN})$; 8 - hydraulic jack $(100 \mathrm{kN}) ; 9-11$ - steel girders; 10 - load cell АЦД/1С-200/4И-1 (200 кН).

Fig. 4. Test setups:

a) series БI-БVI, b) series БVII-БVIII 
The forces registered during static tests, corresponding to the formation of cracks and the ultimate forces, are presented in Tables 3 and 4.

Table 3. Results of static tests under the action of a uniformly distributed load in the span of a beam

\begin{tabular}{|c|c|c|c|c|c|c|}
\hline Series & Beam & $\begin{array}{l}P_{c r}, \\
\mathrm{kN}\end{array}$ & $\begin{array}{c}\mathrm{q} \mathrm{cr}, \\
\mathrm{kN} / \mathrm{m}\end{array}$ & $\begin{array}{l}\mathrm{Pu}, \\
\mathrm{kN}\end{array}$ & $\begin{array}{c}\mathrm{qu}, \\
\mathrm{kN} / \mathrm{m}\end{array}$ & Mode of failure \\
\hline \multirow[t]{2}{*}{ I } & $\begin{array}{l}\text { БІ-1СД18 } \\
\text { (without loading the } \\
\text { cantilever) }\end{array}$ & - & 29,6 & - & 87,3 & Diagonal crack \\
\hline & БІ-2СД18 & 10,4 & 34,7 & 22,5 & 75,0 & $\begin{array}{l}\text { Diagonal crack in the } \\
\text { span }\end{array}$ \\
\hline \multirow[t]{2}{*}{ II } & БІІ-3СД12 & 10,4 & 34,7 & 24,5 & 81,7 & $\begin{array}{l}\text { Diagonal crack in the } \\
\text { cantilever }\end{array}$ \\
\hline & БІІ-4УД12 & 8,4 & 28,0 & 24,5 & 81,7 & $--/ /--$ \\
\hline \multirow{2}{*}{ III } & БІІІ-5СтД15 & 12,4 & 41,4 & 34,6 & 115,3 & $\begin{array}{l}\text { Bending crack on } \\
\text { support B }\end{array}$ \\
\hline & БІІІ-6СтД15 & 14,5 & 48,2 & 36,6 & 122,1 & $\begin{array}{l}\text { Diagonal crack in the } \\
\text { span }\end{array}$ \\
\hline \multirow{2}{*}{ IV } & БIV-7СтС 16,5 & 12,4 & 41,4 & 34,6 & 115,3 & $--/ /--$ \\
\hline & БIV-8СтC16,5 & 12,4 & 41,4 & 37,9 & 126,3 & $---/ /--$ \\
\hline \multirow[b]{2}{*}{ V } & БV-9CC16,5 & 6,4 & 21,3 & 20,2 & 67,5 & $--/ /--$ \\
\hline & БV-10CC 16,5 & 6,4 & 21,3 & 18,5 & 61,6 & $\begin{array}{l}\text { Diagonal crack in the } \\
\text { cantilever }\end{array}$ \\
\hline \multirow[t]{2}{*}{ VI } & БVI-11СтПЦ & 8,4 & 28,0 & 26,5 & 88,5 & $\begin{array}{l}\text { Diagonal crack in the } \\
\text { span }\end{array}$ \\
\hline & БVI-12СПЦ & 6,4 & 21,3 & 18,2 & 60,6 & $--/ /--$ \\
\hline
\end{tabular}

\section{Notes:}

1. $\mathrm{P}_{\mathrm{cr}}-$ point force applied in the cantilever, corresponding to cracking;

2. $\mathrm{q}_{\mathrm{pr}}$ - uniformly distributed load applied in the span of a beam corresponding to cracking;

3. $\mathrm{P}_{\mathrm{u}}$ - point force applied in the cantilever, corresponding to failure;

4. $\mathrm{q}_{\mathrm{u}}$ - uniformly distributed load applied in the span of a beam corresponding to failure.

Table 4. Results of static tests under the action of point loads in the span of a beam

\begin{tabular}{|c|c|c|c|c|c|c|}
\hline \multirow{2}{*}{ Series } & Beam & $\begin{array}{c}\mathrm{P}_{\text {cr, }} \\
\mathrm{kN}\end{array}$ & $\begin{array}{c}\mathrm{P}_{\text {tot,cr, }} \\
\mathrm{kN}\end{array}$ & $\begin{array}{c}\mathrm{P}_{\mathrm{u}}, \\
\mathrm{kN}\end{array}$ & $\begin{array}{c}\mathrm{P}_{\text {tot,u, }} \\
\mathrm{kN}\end{array}$ & Mode of failure \\
\hline \multirow{3}{*}{ VII } & БVII-13CC16,5 & 6,5 & 32,9 & 21,9 & 110,6 & $\begin{array}{c}\text { Diagonal crack in the } \\
\text { cantilever }\end{array}$ \\
\cline { 2 - 7 } & БVII-14CтC16,5 & 14,6 & 73,5 & 34,8 & 175,2 & $\begin{array}{c}\text { Diagonal crack in the } \\
\text { span }\end{array}$ \\
\hline \multirow{2}{*}{ VIII } & БVIII-15CПЦ & 4,5 & 22,8 & 14,6 & 73,4 & $--/ /--$ \\
\cline { 2 - 7 } & БVIII-16СтПЦ & 4,5 & 22,7 & 24,9 & 125,5 & $--/ /--$ \\
\hline
\end{tabular}

\section{Notes:}

1. $\mathrm{P}_{\mathrm{cr}}$ - point force applied in the cantilever, corresponding to cracking;

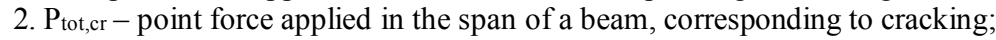

3. $\mathrm{P}_{\mathrm{u}}$ - point force applied in the cantilever, corresponding to failure;

4. $\mathrm{P}_{\mathrm{tot}, \mathrm{u}}$ - point force applied in the span of a beam, corresponding to failure.

According to the above presented procedure for calculation the shear resistance of concrete elements reinforced with FRP bars, the contributions of the shear-transfer actions were calculated for various sections of the $\mathrm{5V}-9 \mathrm{CC} 16,5$ beam, as well as the traditional reinforced beam (БІІІ-6СтД15) (see Figure 5). Table 6 shows the results of comparing the shear resistance calculated by the proposed procedure with the results of an experimental study for various sections. 
a)

b)
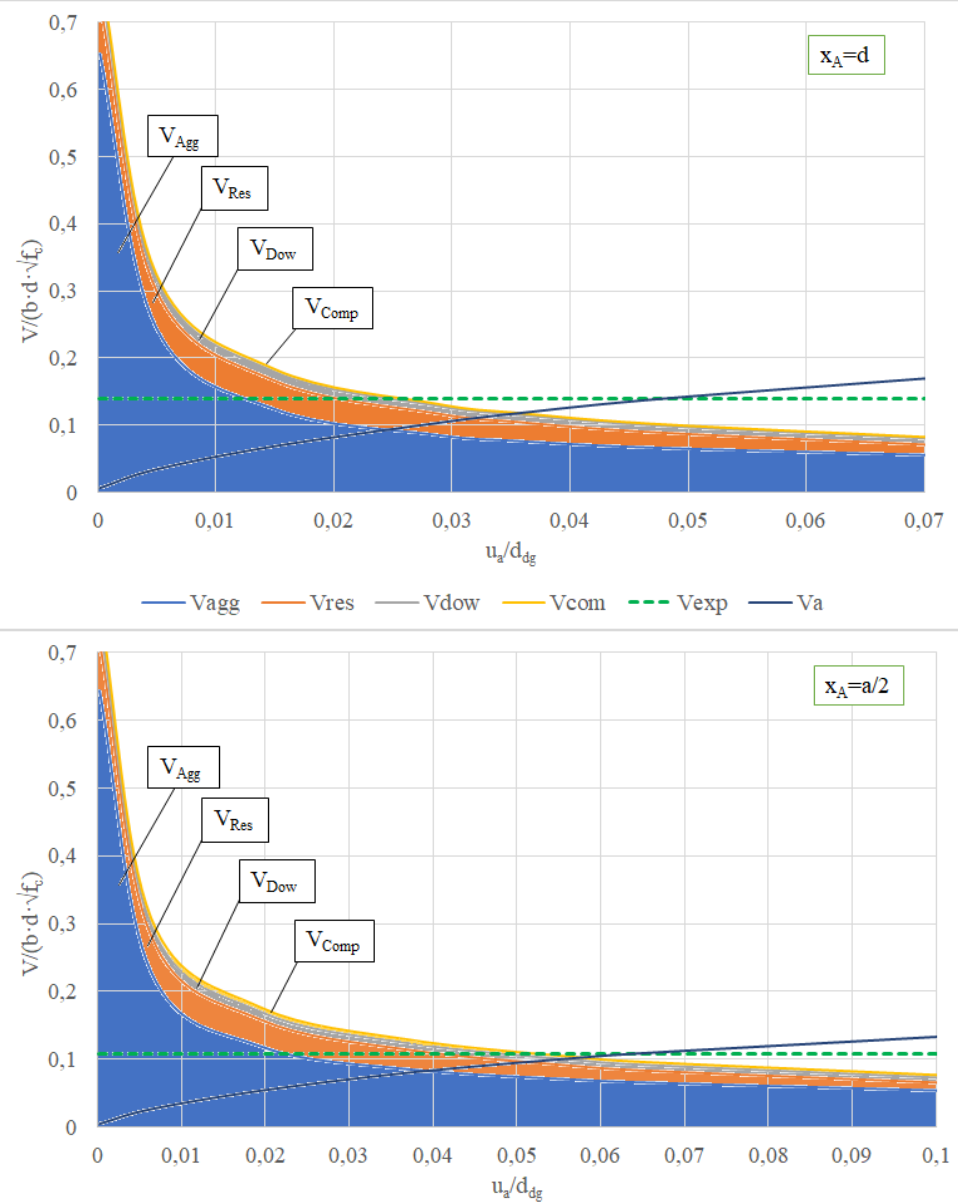

c)
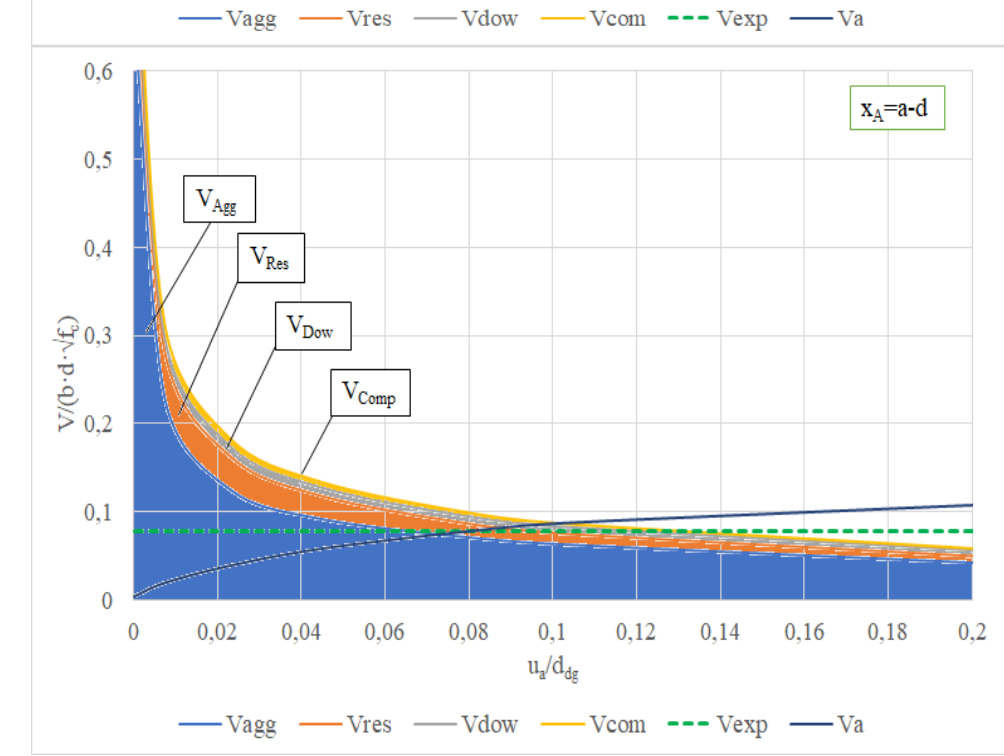
d)

e)
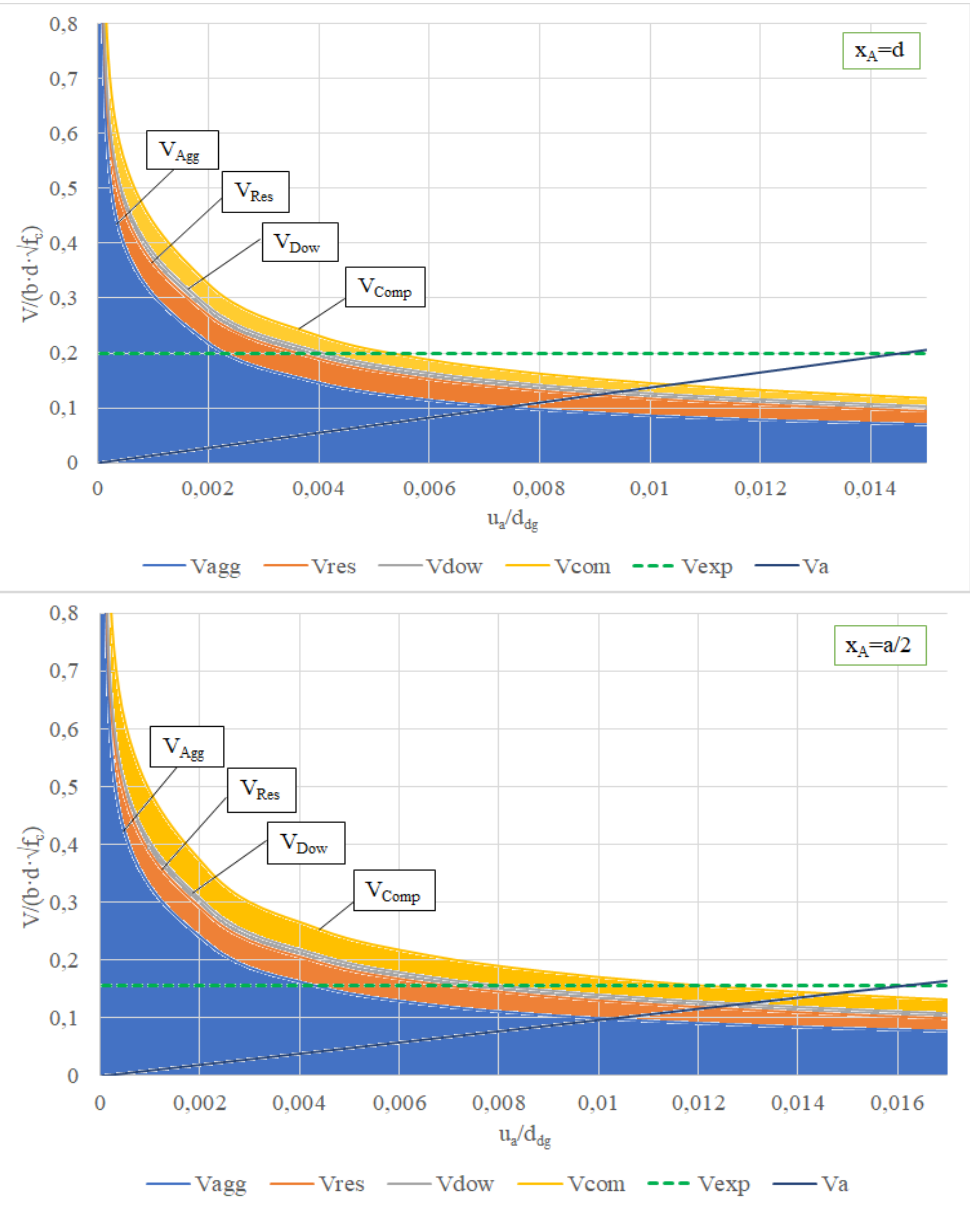

f)

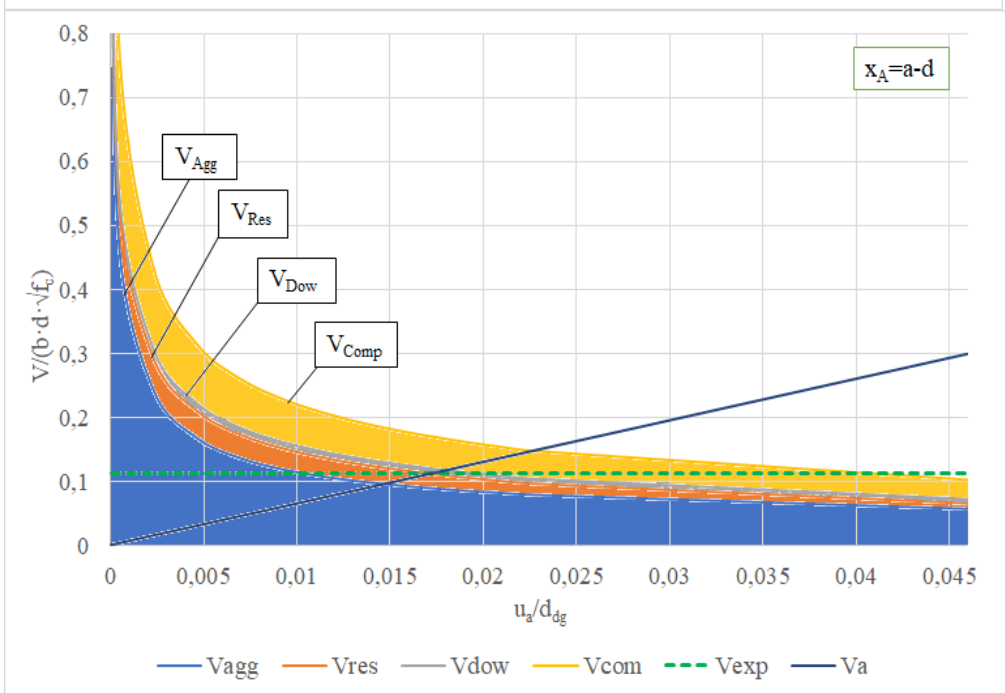

Fig. 5. Failure criterion and load-deformation curve for critical section of beam $5 V-9 C C 16,5$ a) $x_{A}=d$, b) $x_{A}=a / 2$, c) $x_{A}=a-d$ and beam БІІІ-6СтД15 d) $x_{A}=d$, e) $x_{A}=a / 2$, f) $x_{A}=a-d$; shear-transfer actions: aggregate interlock, residual tensile strength of concrete, dowelling action and contribution of the compression zone 
Table 5. Comparison of theoretical values of shear resistance according to the proposed procedure with experimental data for different design sections along the span of FRP-reinforced beam elements

\begin{tabular}{|c|c|c|c|c|c|c|}
\hline Beam & $\begin{array}{l}\text { Reinforcement } \\
\text { type }\end{array}$ & $\begin{array}{l}\text { Mode of } \\
\text { failure }\end{array}$ & $\begin{array}{c}\text { Section, } \\
\mathrm{mm}\end{array}$ & $\begin{array}{l}\mathrm{V}_{\text {theo, }} \\
\mathrm{kN}\end{array}$ & $\begin{array}{l}\mathrm{V}_{\mathrm{exp}}, \\
\mathrm{kN}\end{array}$ & $V_{\text {exp }} / V_{\text {theo }}$ \\
\hline \multirow{3}{*}{$\begin{array}{l}\text { БІ-1СД18 } \\
\text { (without } \\
\text { loading the } \\
\text { cantilever) }\end{array}$} & \multirow{3}{*}{ GFRP } & \multirow{3}{*}{$\begin{array}{l}\text { Diagonal } \\
\text { crack in the } \\
\text { span }\end{array}$} & $\mathrm{d}=270$ & 29,13 & 49,73 & 1,71 \\
\hline & & & $\mathrm{a} / 2=420$ & 24,29 & 36,65 & 1,51 \\
\hline & & & $a-d=570$ & 19,67 & 23,56 & 1,20 \\
\hline \multirow{3}{*}{ БІ-2СД18 } & \multirow{3}{*}{ GFRP } & \multirow{3}{*}{$\begin{array}{l}\text { Diagonal } \\
\text { crack in the } \\
\text { span }\end{array}$} & $\mathrm{d}=270$ & 29,46 & 36,02 & 1,22 \\
\hline & & & $\mathrm{a} / 2=375$ & 25,71 & 28,14 & 1,10 \\
\hline & & & $a-d=480$ & 22,18 & 20,26 & 0,91 \\
\hline \multirow{3}{*}{ БІІ-3СД12 } & \multirow{3}{*}{ GFRP } & \multirow{3}{*}{$\begin{array}{l}\text { Diagonal } \\
\text { crack in the } \\
\text { cantilever }\end{array}$} & $\mathrm{d}=270$ & 33,41 & 24,52 & 0,73 \\
\hline & & & $\mathrm{a} / 2=450$ & 29,13 & 24,52 & 0,84 \\
\hline & & & $a-d=630$ & 26,37 & 24,52 & 0,93 \\
\hline \multirow{3}{*}{ БІІ-4УД12 } & \multirow{3}{*}{ CFRP } & \multirow{3}{*}{$\begin{array}{l}\text { Diagonal } \\
\text { crack in the } \\
\text { cantilever }\end{array}$} & $\mathrm{d}=270$ & 32,83 & 24,52 & 0,75 \\
\hline & & & $\mathrm{a} / 2=450$ & 28,68 & 24,52 & 0,86 \\
\hline & & & $a-d=630$ & 26,23 & 24,52 & 0,94 \\
\hline \multirow{3}{*}{ БV-9CC16,5 } & \multirow{3}{*}{ GFRP } & \multirow{3}{*}{$\begin{array}{c}\text { Diagonal } \\
\text { crack in the } \\
\text { span }\end{array}$} & $\mathrm{d}=270$ & 27,47 & 32,38 & 1,18 \\
\hline & & & $a / 2=375$ & 23,79 & 25,30 & 1,06 \\
\hline & & & $a-d=480$ & 20,32 & 18,22 & 0,90 \\
\hline \multirow{3}{*}{$\begin{array}{c}\text { БV- } \\
10 \mathrm{CC} 16,5\end{array}$} & \multirow{3}{*}{ GFRP } & \multirow{3}{*}{$\begin{array}{l}\text { Diagonal } \\
\text { crack in the } \\
\text { cantilever }\end{array}$} & $\mathrm{d}=270$ & 29,37 & 18,48 & 0,63 \\
\hline & & & $\mathrm{a} / 2=450$ & 25,56 & 18,48 & 0,72 \\
\hline & & & $a-d=630$ & 23,08 & 18,48 & 0,80 \\
\hline \multirow{3}{*}{ БVI-12СПЦ } & \multirow{3}{*}{ GFRP } & \multirow{3}{*}{$\begin{array}{l}\text { Diagonal } \\
\text { crack in the } \\
\text { span }\end{array}$} & $\mathrm{d}=270$ & 26,86 & 29,09 & 1,08 \\
\hline & & & $\mathrm{a} / 2=375$ & 23,29 & 22,73 & 0,98 \\
\hline & & & $a-d=480$ & 19,83 & 16,36 & 0,83 \\
\hline \multirow{3}{*}{$\begin{array}{c}\text { БVII- } \\
\text { 13CC16,5 }\end{array}$} & \multirow{3}{*}{ GFRP } & \multirow{3}{*}{$\begin{array}{l}\text { Diagonal } \\
\text { crack in the } \\
\text { cantilever }\end{array}$} & $\mathrm{d}=270$ & 28,84 & 21,94 & 0,76 \\
\hline & & & $\mathrm{a} / 2=450$ & 25,12 & 21,94 & 0,87 \\
\hline & & & $a-d=630$ & 22,73 & 21,94 & 0,97 \\
\hline \multirow{2}{*}{$\begin{array}{c}\text { БVIII- } \\
15 \mathrm{CПЦ}\end{array}$} & \multirow[b]{2}{*}{ GFRP } & \multirow{2}{*}{$\begin{array}{c}\text { Diagonal } \\
\text { crack in the } \\
\text { span }\end{array}$} & $\mathrm{d}=270$ & 38,43 & 29,72 & 1,29 \\
\hline & & & $\mathrm{a} / 2=230$ & 27,91 & 29,72 & 1,06 \\
\hline
\end{tabular}

Based on the results of the comparative analysis presented in Table 6, the critical section for concrete beam elements reinforced with FRP bars subjected to uniformly distributed load in the span is at a distance $\boldsymbol{x}_{\boldsymbol{A}}=\boldsymbol{a} / \mathbf{2}$ (the shear span under a uniformly distributed load is determined from the expression $a=L / 2$, where $L$ is the beam span). However, it should be noted that for beam elements subjected to point loads in a span, the critical section is at a distance $\boldsymbol{x}_{A}=\boldsymbol{a}-\boldsymbol{d}$ (for beam elements with a shear span $a / d \geq 2,5$ ), which, as in the case of a uniformly distributed load, differs on the position of critical sections in beam elements with traditional reinforcement with steel bars [14].

\section{Failure criterion}

For design purposes, instead of calculating the contributions of the shear-transfer actions by integrating stresses along the critical shear crack, there was a hyperbolic failure criterion [8].

The failure criterion was obtained against the background of experimental data [17] (see Figure 6) by approximating the exponential expression: 


$$
\frac{V_{R, c}}{b \cdot d \cdot \sqrt{f_{c}}}=k \cdot\left(\frac{w_{A}}{d_{d g}}\right)^{-1 / 2}
$$

where $k=0,0224$;

$d_{d g}=16+d_{g}$

$d_{g}$ - maximum aggregate size, $\mathrm{mm}$.

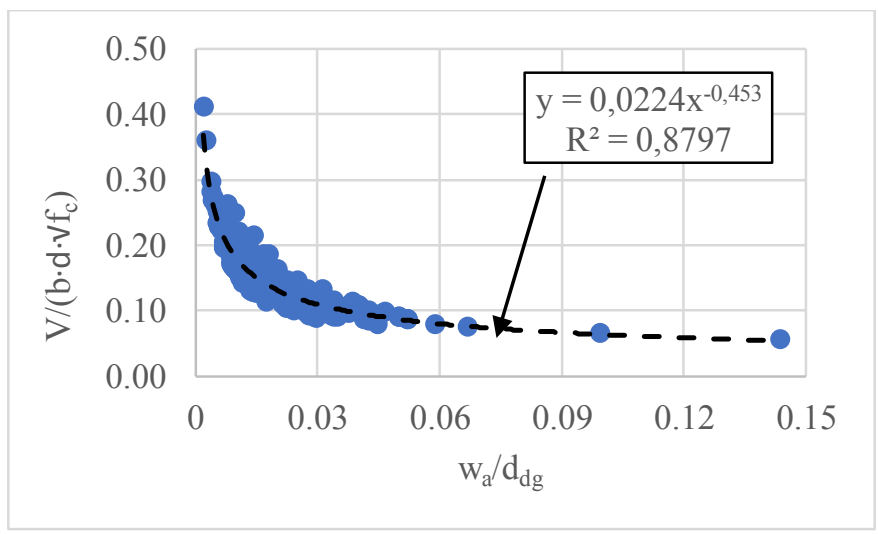

Fig. 6. Failure criterion of the CSCT+"bond-slip" against the background of the experimental database

Blue points in Figure 6 represent the intersections of the failure criterion calculated according to the proposed procedure in the control section $x_{A}=a-d$ for beam elements with a shear span $a / d \geq 2,5$ and the "load - crack opening width" relationship.

As can be seen from Figure 6, the obtained criterion for elements reinforced with FRP bars has practically the same analytical description as in the case of using reinforcement from steel bars. The difference in criterion (17) is the value of the coefficient $k=0,0224$ (for steel bars, according to the approximation results, $k=0,019)$.

The modified shear resistance model of the CSCT shows a good agreement with the experimental data (see Figure 7). So, for beams with a shear span $a / d \geq 2,5$ and a control section $x_{A}=a-d$ simulation error parameters were: $b\left(V_{R d, \exp } / V_{R, \text { theo }}\right)=0,77$ with a value of $\mathrm{CoV}$ of $V_{x}=24,3 \%$.

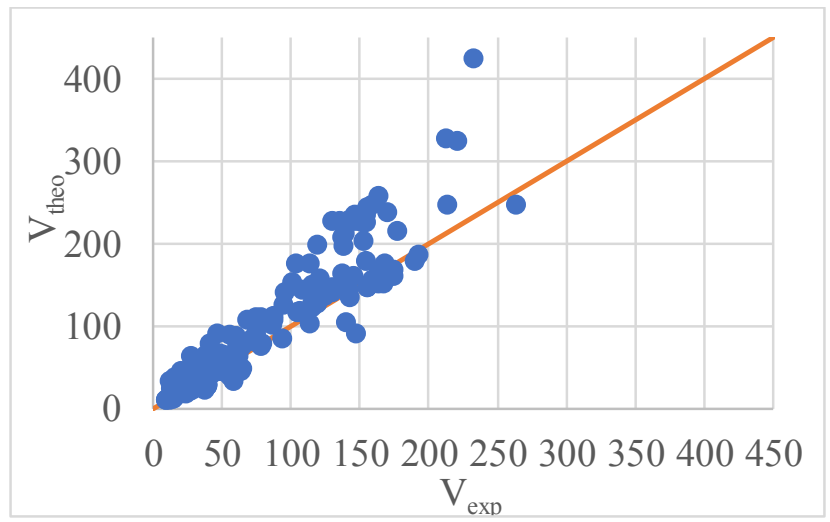

Fig. 7. Comparison of theoretical values of shear resistance according to the proposed procedure (at $x_{A}=a-d$ ) with experimental data (296 elements reinforced with FRP with a shear span $a / d \geq 2,5$ ) 


\section{Conclusion}

This paper presents a methodology for calculating the shear resistance of concrete elements reinforced with FRP bars, based on the provisions of the Critical Shear Crack Theory (CSCT) and the modified "bond-slip" law. This procedure has been verified on the results of our own experiments, which shows good convergence. For design purposes, a failure criterion was obtained against the background of an experimental database (296 beam elements with a shear $\operatorname{span} a / d \geq 2,5$ ).

\section{References}

1. FRP reinforcement in RC structures: fib 2007, Task Group 9.3 (Fiber-Reinforced Polymer) Reinforcement for Concrete Structures (2007)

2. ACI-440-15. Guide for the design and construction of concrete reinforced with FRP bars (2015)

3. ISIS-M03-01. "Reinforcing Concrete Structures with Fiber Reinforced Polymers," (2001)

4. JSCE (Japan Society of Civil Engineers). "Recommendation for design and construction of concrete structures using continuous fiber reinforcing materials." (1997)

5. British Institution of Structural Engineers, Interim Guidance on the Design of Reinforced Concrete Structures using Fiber Composite Reinforcement, BISE-1999 (1999)

6. Advisory Committee Technical Recommendations Construction, Guide for the Design and Construction of Concrete Structures Reinforced with Fiber-Reinforced Polymer Bars (CNR-DT203-06) (2006)

7. ACI-318-19. Building code requirements for structural concrete and commentary (2019)

8. A. Muttoni, M. Fernández Ruiz, ACI Str. J., 105, 72 (2008)

9. $f i b$ Model Code for Concrete Structures 2010 (2013)

10. M. Fernández Ruiz, A. Muttoni, J. Sagaseta, Eng Struct., 99, 72 (2015)

11. S. Campana, A. Anastasi, M. Fernández Ruiz, A. Muttoni, Mag Concr Res., 65, 404 (2013)

12. F. Cavagnis, M. Fernández Ruiz, A. Muttoni, Eng Struct., 103, 73 (2015)

13. F. Cavagnis, M. Fernández Ruiz, A. Muttoni, Struct Conc., 19, 49 (2017)

14. F. Cavagnis, M. Fernández Ruiz, A. Muttoni, Eng. Struct., 157, 300 (2018)

15. R. Eligehausen, E. P. Popov, V. V. Bertero, Local bond stress-slip relationships of deformed bars under generalized excitations, Report no. 83/23, EERC, University of California, Berkeley (1983)

16. E. Cosenza, G. Manfredi, R. Realfonzo, Composites: Part B, 33, 493 (2002)

17. S. Cholostiakow, M. Di Benedetti, M. Guadagnini, M. Kaszubska, D. Szczech, R. Kotynia, Shear database of RC FRP beams without shear reinforcement, The University of Sheffield, Dataset (2017) 